\title{
DETERMINATION OF SURFACE MOISTURE AND PARTICLE SIZE DISTRIBUTION OF COAL USING ONLINE IMAGE PROCESSING
}

\author{
P. Choudhary 1 , T. Maloo², H. Parida², P. Khatri², B. Deo", P. Chattopadhyay ${ }^{3}$ \\ ${ }^{1}$ IIT Bhubaneswar, School of Mechanical Sciences, Odisha, India \\ 2IIT Bhubaneswar, School of Minerals, Metallurgical and Materials Engineering, Odisha, India \\ ${ }^{3}$ Tata Steel Long Products Limited, Joda, Odisha, India
}

(Received: April 3, 2020; Accepted: June 29, 2020)

\begin{abstract}
Production of sponge iron requires iron ore, coal, and dolomite. The quality of sponge iron is affected by particle size variation and moisture content of the feed materials. In the present work, image processing was used to detect both particle size and moisture variation of the feed materials on an online basis. Noise and signal irregularities in images were removed by image analysis through MATLAB. Continuous (online, every 30 minutes) images were taken over a coal bed which was moving on a conveyor belt. It was a challenge to determine the particle size distribution and surface moisture of coal online. The distribution of reflectivity of coal in the image varied according to the moisture content and particle size. It affected the intensity information of the image which was then used to predict the surface moisture content of the coal. The method is now being used successfully in a processing plant.
\end{abstract}

Key words: Image Processing; Machine Vision; Coal; Size distribution; Moisture content; Rotary Kiln.

\section{Introduction}

The rotary kiln for sponge iron production uses iron ore $(62-65 \% \mathrm{Fe})$ and inferior quality coal with the following properties: up to $25 \%$ ash, particles size smaller than $3 \mathrm{~mm}$ reaching up to $70 \%$, and surface moisture content up to $15 \%$. There are three rotary kilns at TATA Steel Long Product Limited (TSLPL), Keonjhar, Odisha, India which is an associate company of TATA steel, India. TSLPL has a total production capacity of $+425,000$ TPA. Due to the economical nature, there is no means of control on particle size and moisture for the raw materials used in sponge iron production. Therefore, with the purpose of optimal kiln operation, it is necessary to monitor the particle size distribution and moisture content of the coal continuously because these are the principle features for the processing operation strategies. The policy opted by the control unit is such that it varies other useful parameters to compensate for the effect of particle size and moisture on quality. Previously, the moisture content and particle size data were obtained in the laboratory by using conventional methods, which were only limited to three times a day and hence inadequate for continuous process control requirements. It may be noted that the present work is focused on the surface moisture of coal and not the internal (structural or fixed) moisture content of coal.

A specific range of particle size of coal is best suited for reducing the iron ore, but in actual practice, the size range keeps on changing from lot to lot. If a finer size fraction is larger than the coal, it burns faster which leads to an increase in the kiln temperature in particular sections followed by the formation of accretion on the walls of the kiln. The fines ( $-3 \mathrm{~mm}$ particles) are unable to reach the required distance inside the kiln from the coal throw pipe. This causes starvation of coal in some regions. Inadequate reduction atmosphere leads to poor quality of sponge iron (a low Fe content in the sponge). Figure 1 shows the effect of particle size on quality: if the size of coal is larger than the specified range (i.e. less fines) then it will not burn in time leading to a loss in the internal temperature of the kiln [1, 2] in some regions. It also affects coal consumption per ton of iron ore. The regions where fine particles burn early experience a local increase in temperature and this affects the overall quality of sponge iron, Figure 1. Image processing is a suitable

\#Corresponding author: bdeo@iitbbs.ac.in

doi: 10.5937/JMMA2001037C 
method for determining particle size online. If the particle size is known in advance then the operating parameters can be adjusted effectively.

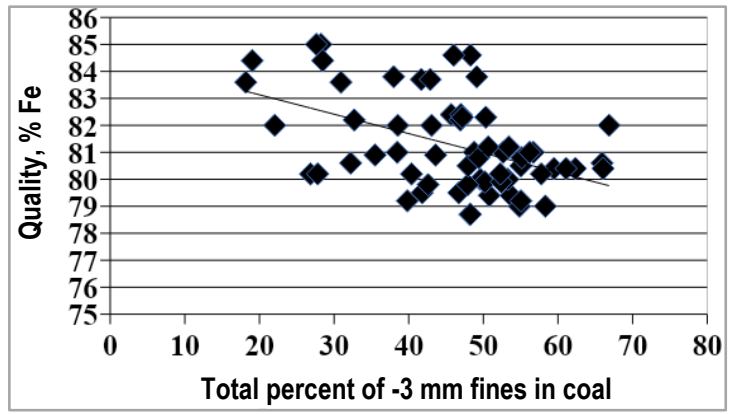

Figure 1 Effect of the percentage of $-3 \mathrm{~mm}$ fraction in coal on the quality of sponge ( $\% \mathrm{Fe})$ from the rotary kiln [3]

Variation in moisture also, along with variations in coal particle size, affects the quality of sponge iron produced. At high temperatures, the moisture present in the coal reacts with carbon and produces carbon monoxide and hydrogen by an endothermic reaction:

$\mathrm{H}_{2} \mathrm{O}(g)+\mathrm{C} \rightarrow \mathrm{CO}(g)+\mathrm{H}_{2}(g)$

Even though the reducing gases $\left(\mathrm{CO}+\mathrm{H}_{2}\right)$ are produced, and hydrogen is more efficient as a reducing agent for iron oxide than $\mathrm{CO}$, due to the sudden fall in internal temperature the overall reduction efficiency decreases, which directly reduces the quality of the product.

Machine vision is already becoming an integral part of our industries. It assists the enterprises in obtaining quality products by deciding optimal feed inputs. In material processing industries, it is essential to know the characteristics of the raw material for process control. Machine vision can be used to reduce laboratory time by providing the information continuously. The use of image processing for particle size and moisture determination has been reported earlier. Some researchers have reported different techniques to extract moisture and particle size information using image processing [2 - 17]. But the property which was used for moisture determination was the variation in reflectivity of coal surface with moisture $[3,7,12]$. Kontny in his paper showed the methods using laser triangulation and image processing for estimation of volume and size distribution of aggregate transported on conveyor belts using the LabVIEW environment [15]. Zhang showed a method to overcome the error due to the overlapping particles by fitting the results of overlapping particles calculated using statistical interval method [10]. Zhang and Yang showed different color and texture features (total thirty-eight features). Later, genetic algorithms (GA) and SVM were used to determine the most effective features for ash content prediction $[13,17]$. Thurley showed for limestone (a) a method using a laser scanner to determine the overlapped and non-overlapped fragments and (b) the particle size measurements with the difference in size ranges [9].

This paper shows that instead of simply using the aggregate of intensity, additional features like mean, variance, skewness, and Kurtosis can be incorporated to better represent the variation and distribution of intensity throughout the image. The energy and entropy of the grayscale image represent uniformity of the grayscale intensity level [4 - 13]. Out of these, the most effective parameters for moisture detection are reported in the present work. A distinctive feature of the present work is that the image processing experiments were done with LED light and the same image was used to predict the moisture and particle size of the coal on a moving bed.

Video camera and the lights were placed above the moving bed for on-line measurements. Optimal height for the best and simultaneous determination of moisture and particle size was determined during the thorough experiments. The samples were preserved and transported in sealed bags so that no moisture was lost in-transit (the samples meant for the laboratory part). Multiple trials were done with the same sample to check the consistency.

In actual plant practice, the information obtained on moisture and particle size is now fed on-line to the process control system of the rotary kiln [14]. Mathematical models are used for advising appropriate actions to be taken for adjusting the control parameters like air flow rate, coal feed rate, the rotation speed of kiln, ore to coal ratio, etc.

The present work also constitutes a part of the overall program at TSLPL on the implementation of "Industry 4.0" (or "smart factory").

\section{Particle size distribution of coal}

In the present work a good coal is one which has: a typical moisture content of $8.3 \% \pm 1 \%$, and particle size distribution of $2.1 \%$ of $+20 \mathrm{~mm} ; 1.5 \%$ of $+18 \mathrm{~mm} ; 3.2 \%$ of $+15 \mathrm{~mm} ; 14.7 \%$ of $+8 \mathrm{~mm} ; 12.1$ of $+5 \mathrm{~mm} ; 9.7 \%$ of +3 $\mathrm{mm} ; 10.3 \%$ of $+2 \mathrm{~mm} ; 12.9 \%$ of $+1 \mathrm{~mm} ; 33.5 \%$ of $-1 \mathrm{~mm}$. 
The objective of image analysis is to find out the total \% of $-3 \mathrm{~mm}$ fractions in the coal, and not the entire particle size distribution.

Initial laboratory experiments were done at a fixed height of a camera of $400 \mathrm{~mm}$, placed normal to the sample surface. An image (194 x 176 pixels) was taken under the LED light and was used for particle size distribution analysis. As a counter check, a conventional sieve analysis was also done. MATLAB was used for image analysis. The image was a 3D matrix with red, green, and blue as its three dimensions [15]

In the previous work [3], the process of analysis was divided into four steps as follows: Step 1: RGB to BW image conversion for dimension reduction; Step 2: an attempt was made to smoothen the shape of the particle surface in the binary image; Step 3: The area of the particle was calculated; Step 4: classification of particles was based on an area of $3 \mathrm{~mm}$ particles at the same 400 $\mathrm{mm}$ distance and cross-validation was done with the sieve analyzed data [16]. It was observed that the particle size prediction was not accurate when the percentage of fine particles was high; when the percentage of particle size of less than $3 \mathrm{~mm}$ increased, the error increased as well. After creating a boundary around each particle (the red marked boundary in Figure 2), it was observed that the fine particles which were positioned very close to each other or the particles which overlapped each another appeared as a single particle causing an anomaly in prediction. This anomaly was reduced in the present work by tuning and training by various MATLAB functions (discussed in the next section).

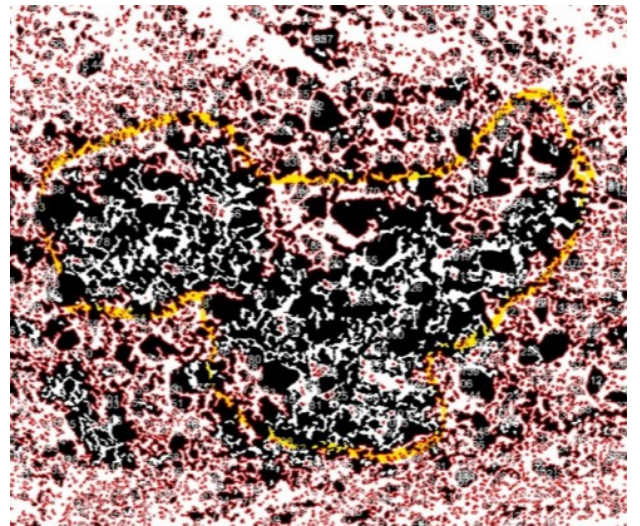

Figure 2 Clustered distinct coal particles forming a single particle with larger area creating irregularity in prediction (highlighted in yellow boundary)

\section{Tuning and training MATLAB functions}

In order to reduce prediction errors [3], boundaries were constructed around each particle using MATLAB functions. For example, 'bwlabel' was used for labeling each particle completely separated from one another. 'Regionprops' was used for numbering each particle and finding the centroid coordinate. 'Bwboundries' was used as the label from 'bwlabel' to create a boundary around each particle. 'Regionprops' was also used for tuning the parameters to create an effective boundary around each particle [16]. Structuring and noise removal were done using morphological operations from MATLAB as shown in Figure 3.

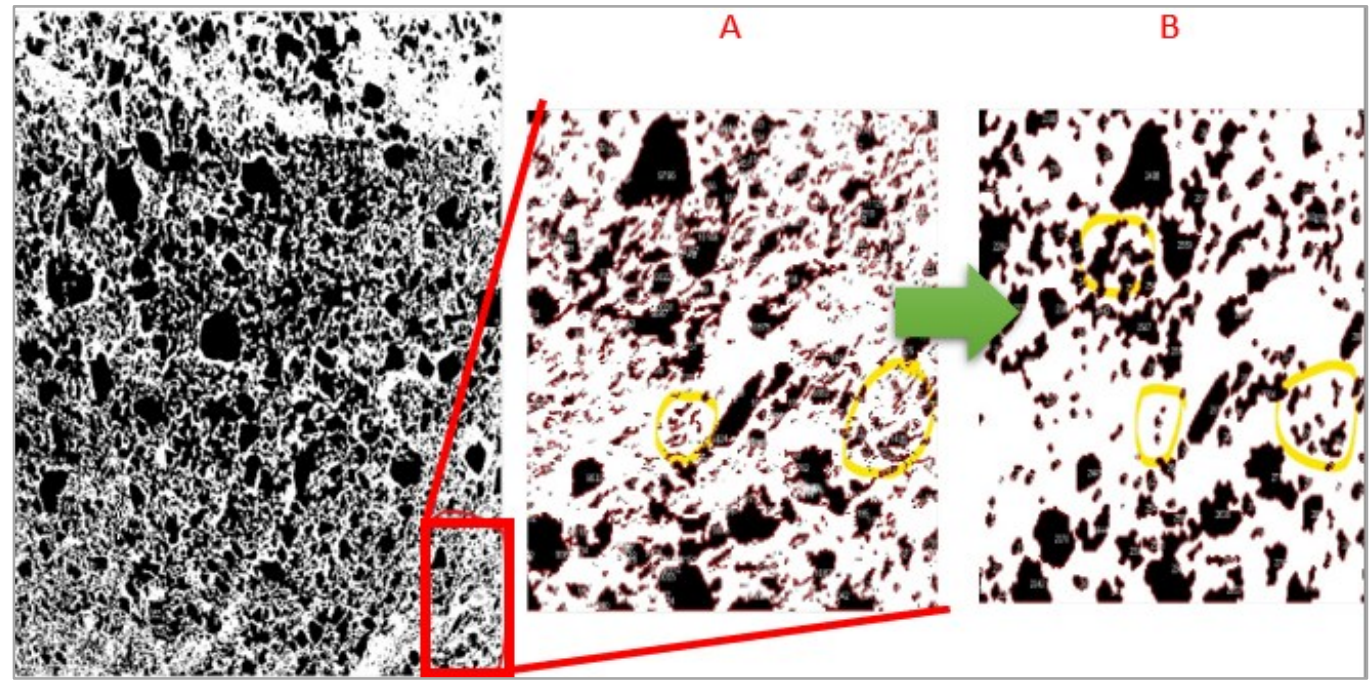

Figure 3 Before $(A)$ and after $(B)$ morphological operation 
For example, 'bwareaopen' connected the group of pixels with other groups; 'bwmorph' helped to give structure to the particles based on a majority (sets a pixel to 1 if five or more pixels in its $3 \times 3$ neighborhood were ' 1 '; otherwise, it set the pixel to ' 0 ').

The identification of individual particles, as mentioned earlier, became difficult when clustering of particles occurred. For such cases, it became necessary to draw the line of segmentation and these operations came under 'bwdist' and 'watershed' [16].

1. The function 'bwdist' computed the Euclidean distance-transform of the binary image BW. For each pixel in BW, the objective of 'bwdist' was to calculate the Euclidean distance. It helped to find out the rate of change of intensity within the specified region.

2. The function 'watershed' was used for segmentation of particles by treating the image as a surface wherein the light pixels represented high elevations and the dark pixels represented low elevations; hence it was necessary to create a gradient using 'bwdist'.

If these functions were used directly, then oversegmentation occurred, as shown in Figure 4.

To remove over-segmentation from the image, the image had to be modified before applying 'watershed'. The reason for this was that each local minimum (maxima was at the boundary of a particle) became a catchment basin; the catchment basin was a local or regional minimum in the image which was generally at the center of a particle. By using 'bwdist', a distance transformation was created.

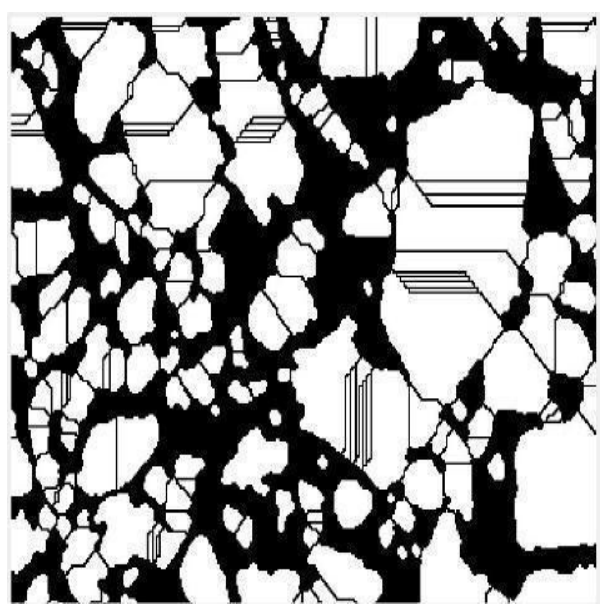

Figure 4 Over-segmentation after using the watershed function

The separation line between different regions of group's pixels, where overflow took place, was called the segmentation line [16]. The reason behind oversegmentation was the formation of multiple tiny local minima where each pair of minima led to the formation of a segmentation line, as shown in Figure 5.

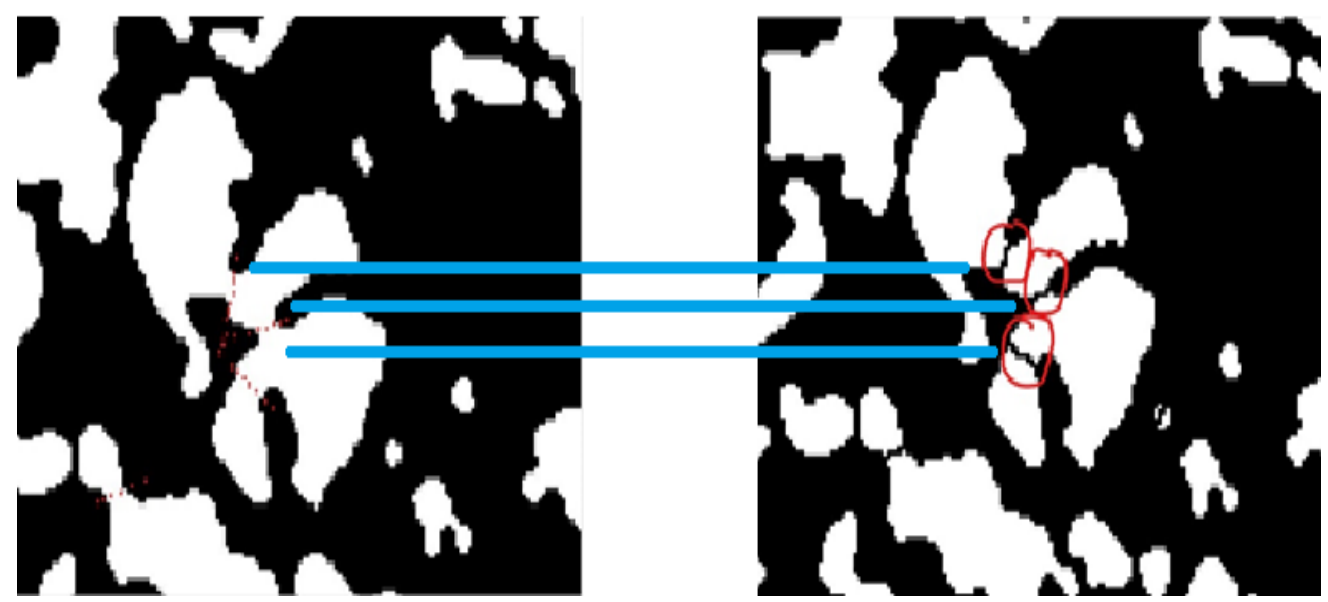

Figure 5 Before and after segmentation (joined particle are segmented)

To overcome over-segmentation, the tiny local minima needed to be filtered out using 'imextendedmin'. The distance transform was modified in a way that no minima occured at the filtered-out locations. This was called 'minima imposition' and was implemented via the function 'imimposemin'; 'minima imposition' prevented the formation of tiny minima. The complete sequence of image processing is shown in Figure 6. 


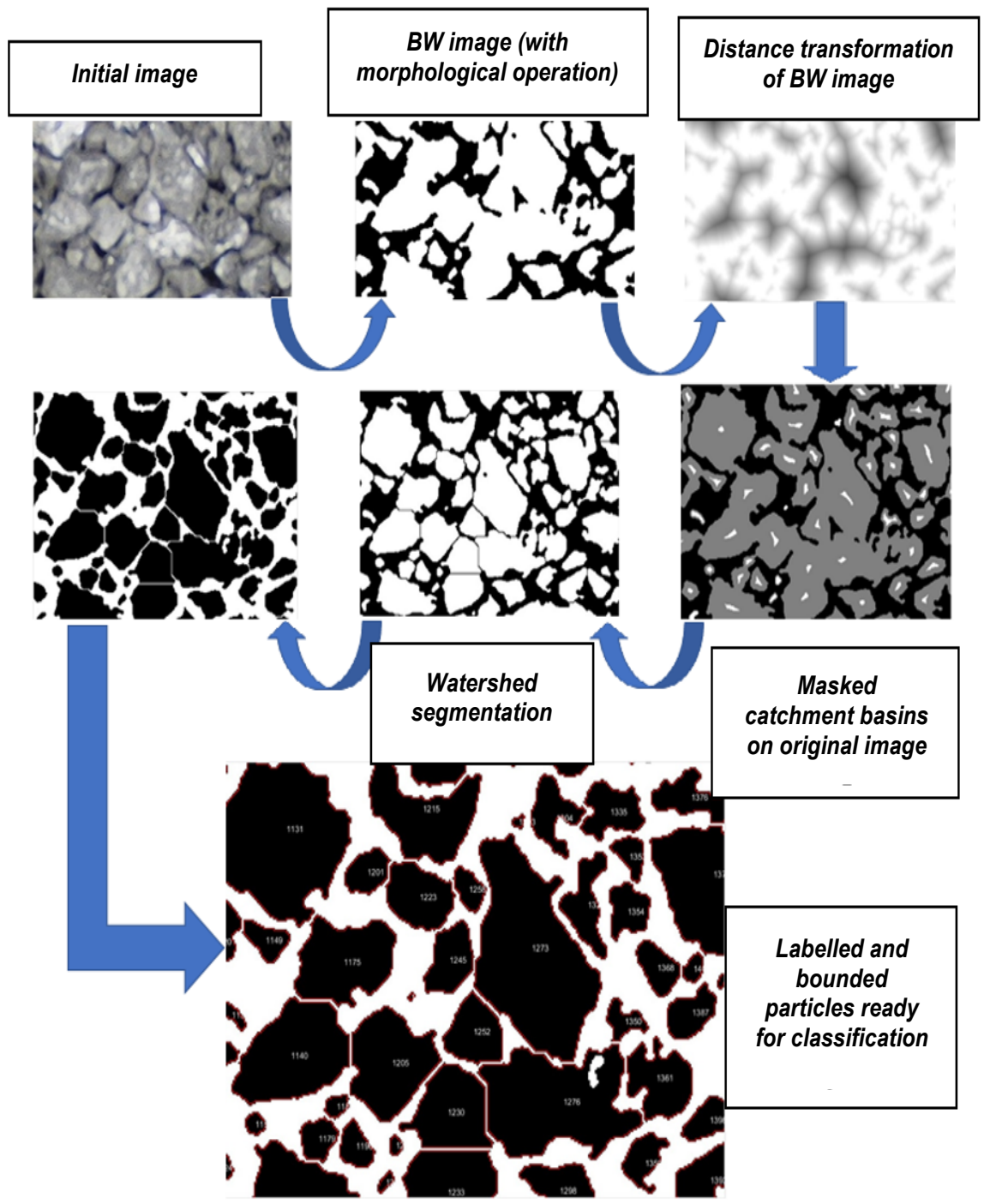

Figure 6 Complete pipeline of image analysis

The model obtained with the above procedure provided the lowest error. The error was evenly distributed for all types of samples whether the percentage was high or low. This new approach decreased the mean error by a factor of 10. It is suggested that this approach for particle size determination may be used for multiple raw materials irrespective of the size and shape of a particle. Almost no tuning would be needed. Results of the particle size estimator with and without watershed were compared in Table 1 for 19 different samples. This method is now regularly used for on-line determination of particle size at TSLPL.

\section{Surface moisture content of coal}

The surface reflectance of coal varied with its surface moisture content. This difference in surface reflectivity of coal with different surface moisture contents thus resulted in different pixel intensity information in its image. This pixel intensity information can, therefore, be used to predict the moisture content of coal. The intensity information of images was calculated using the MATLAB code. As an example, the difference in intensity information of two coal samples with different moisture contents is shown in Figure 7(a) and $7(\mathrm{~b})$. 
Table 1 Error in particle size with watershed and without watershed

\begin{tabular}{|c|c|c|}
\hline $\begin{array}{l}\text { SAMPLE } \\
\text { NO. }\end{array}$ & $\begin{array}{c}\text { Error with } \\
\text { Modified } \\
\text { Watershed }\end{array}$ & $\begin{array}{c}\text { Error without } \\
\text { Watershed }\end{array}$ \\
\hline 1 & 5.66 & 3.51 \\
\hline 2 & 1.35 & -7.87 \\
\hline 3 & 5.47 & -5.66 \\
\hline 4 & 4.95 & -7.44 \\
\hline 5 & -1.29 & 2.34 \\
\hline 6 & -0.92 & 15.55 \\
\hline 7 & 0.78 & -12.19 \\
\hline 8 & -1.86 & -6.97 \\
\hline 9 & -2.73 & -12.59 \\
\hline 10 & -13.01 & -18.31 \\
\hline 11 & -3.5 & -10.42 \\
\hline 12 & -10.06 & 0.96 \\
\hline 13 & -9 & -13.52 \\
\hline 14 & 2.5 & -9.32 \\
\hline 15 & -4.4 & -3.87 \\
\hline 16 & 2.71 & -18.99 \\
\hline 17 & 1.29 & -19.22 \\
\hline 18 & 2.5 & -10.13 \\
\hline \multirow[t]{3}{*}{19} & 6.48 & -7.47 \\
\hline & Mean error: -0.69 & Mean error: -7.45 \\
\hline & $\begin{array}{c}\text { Standard } \\
\text { deviation: } 5.47\end{array}$ & $\begin{array}{c}\text { Standard } \\
\text { deviation: } 8.58\end{array}$ \\
\hline
\end{tabular}

All the images were made up of three primary colors red, green, and blue. The variation of intensity information with surface moisture was studied by formulating two different MATLAB based models. When the image was loaded in the workspace of MATLAB, it was uploaded as a $3 \mathrm{D}$ matrix of red, green, and blue intensity information. In the first model, the RGB image was converted into a grayscale image in which the $3 \mathrm{D}$ matrix was converted to an equivalent 2D matrix. This 2D matrix of a grayscale image was, in turn, used to predict the surface moisture content of coal.

In the second model, instead of converting the RGB (3-D matrix) of the image to an equivalent 2-D matrix, the red, green and, blue intensity information was directly used to predict the surface moisture of coal. From the red, green, and blue intensity, DN (Digital Number) values were calculated, as suggested in [11]. The DN value of each pixel with red, green, and blue intensity represented as ' $r$ ', ' $g$ ', and ' $b$ ' respectively was calculated in the following way:

$D N=(0.2999 \times r)+(0.5870 \times g)+(0.1140 \times b)$

The calculated DN values were used to predict the surface moisture of coal. No significant difference was observed in the results of the grayscale image and RGB images, Figure 8.

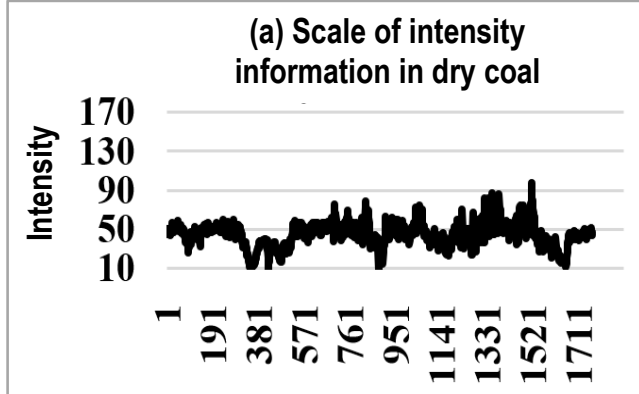

Pixel Coordinate

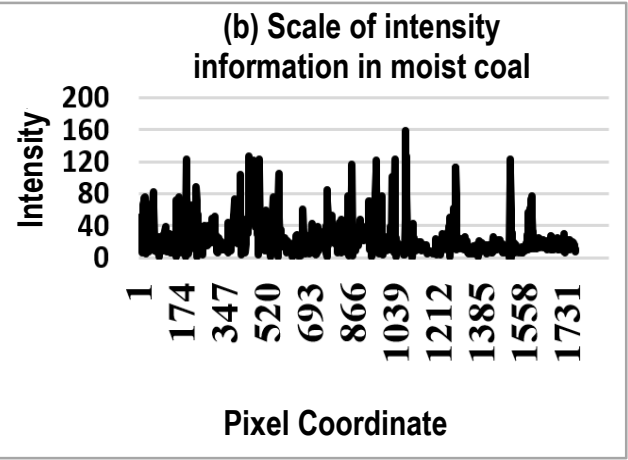

(b) Scale of intensity information in moist coal

Pixel Coordinate

Figure 7 Images were taken in flashlight: (a) scale of intensity information for dry coal (b) scale of intensity information for moist coal

Three different light sources LED light, normal light (tube light 40 watts), and IR lamp were used to select the best one. In each case samples of $0.02 \mathrm{~kg}$ coal with moisture varying from $0 \%$ (dry coal), $2-3 \%, 7-8 \%, 12$ $13 \%, 17-18 \%$, and $22-23 \%$ were prepared in the laboratory. Five images of each sample were taken with a camera normal to the surface at a height 400 $\mathrm{mm}$, under a light source. The variation of intensity information in the image with its respective moisture content was studied. In LED light and IR lights, the trend can be observed up to $25 \%$ moisture, Figure $9(b)$. Whereas in the case of normal tube light, the trend saturated after approximately 12\% moisture, Figure 9(a). 

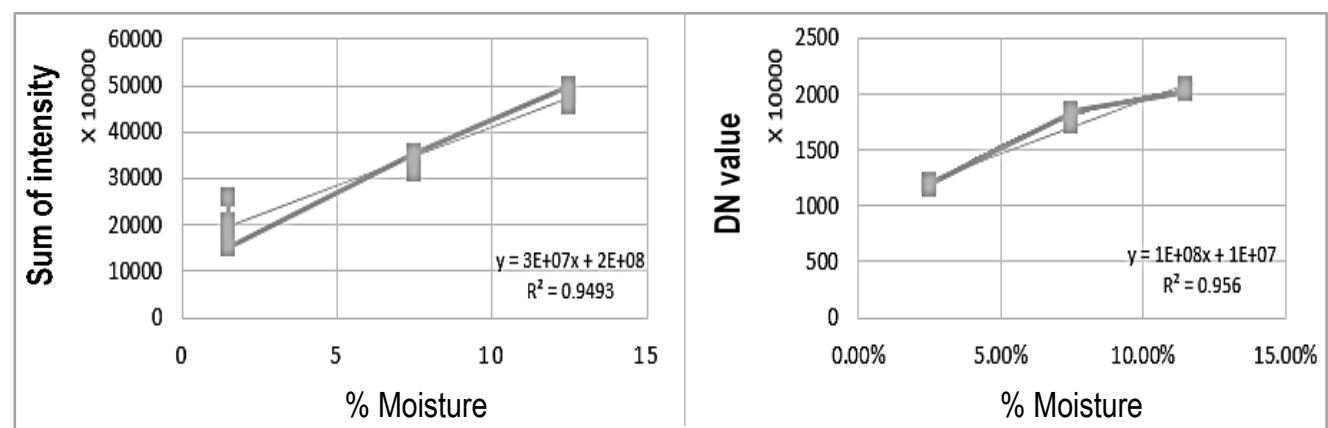

Figure 8 Plots of moisture (range 1.5\% - 13\%) with (a) sum of intensity using grayscale images and, (b) the DN values using RGB images

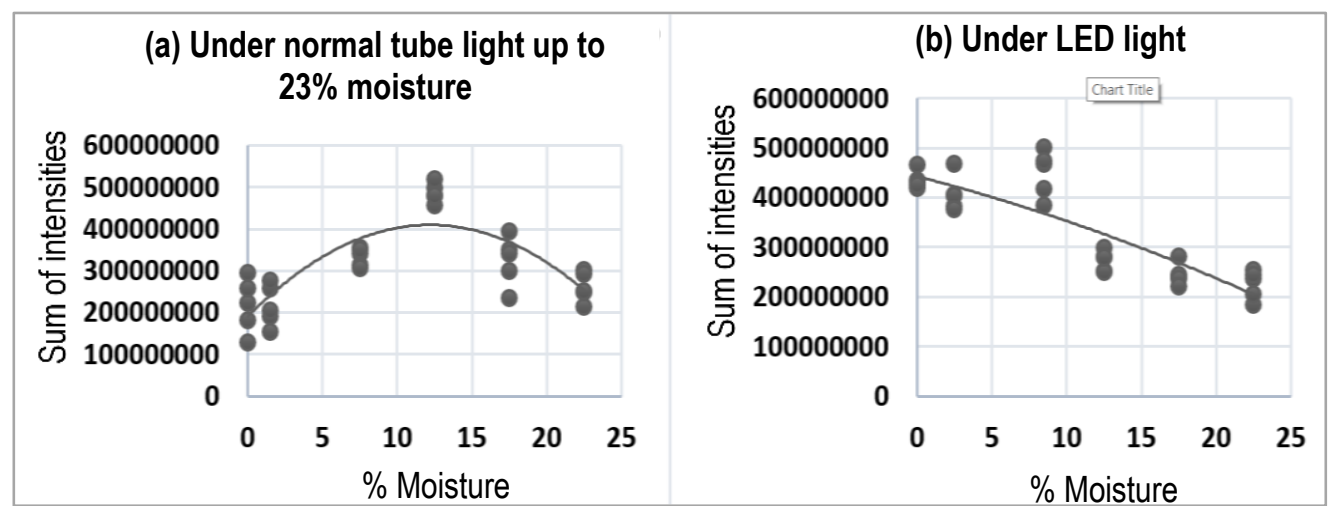

Figure 9 Sum of intensities under (a) normal and (b) LED light

It can be observed from Figure 9 (a) and (b) that by using LED light the moisture can be detected up to $25 \%$ compared to approximately $12 \%$ by using normal tube light.

\section{Improvement and its observation}

An apprehension was that the texture and the intensity distribution pattern throughout the image may play a significant role in improving the model for predicting the moisture in the coal through machine vision $[13,17]$. A list of features is mentioned below and out of these the most effective parameters were selected for moisture determination by considering intensity, digital number, intensity distribution, and texture.

$$
\begin{aligned}
& p(b)=\frac{N(b)}{N} \\
& \mu=\sum_{b=0}^{255} b \times p(b) \\
& \sigma^{2}=\sum_{b=0}^{255}(b-\mu)^{2} \times p(b)
\end{aligned}
$$

$S=\sum_{b=0}^{255} \frac{\left[(b-\mu)^{3} \times p(b)\right]}{\sigma^{3}}$

$K=\sum_{b=0}^{255} \frac{\left[(b-\mu)^{4} \times p(b)\right]}{\sigma^{4}}$

$G=\sum_{b=0}^{255}[p(b)]^{2}$

$H=-\sum_{b=0}^{255} p(b) \times \log \log [p(b)]$

$L=\frac{N_{100}}{N} \times 100 \%$

The parameter, 'b' represented grayscale intensity level varying from 0 to 255 , ' $N(b)$ ' was a total number of pixels having ' $b$ ' pixel intensity and ' $N$ ' was the total number of pixels in the image. Mean (Eq. 4), variance (Eq. 5), skewness (Eq. 6), and kurtosis (Eq. 7) were the four-momentums a.k.a. color distribution momentums. ' $G$ ' (Eq. 8) and ' $\mathrm{H}$ ' (Eq. 9) showed the energy and entropy of the grayscale image which represented the histogram uniformity of the grayscale intensity level. 'L' (Eq. 10) was 
the probability of the top hundred intensity level in the grayscale image $(0-255)$.

The laboratory trials for simultaneous determination above-mentioned parameters required tuning with respect to actual moisture. Experiments were done to cover different types of conditions. The samples with moisture content of $6 \%, 8 \%, 10 \%$, and $14 \%$ were prepared with uniform particle size. The image was captured for a $0.06 \mathrm{~kg}$ coal sample by using a 13megapixel camera at a height of $300 \mathrm{~mm}$.

Based on the $\mathrm{R}^{2}$ value of each feature (Table 2 ) on different samples of particle size: $1 \mathrm{~mm}, 3 \mathrm{~mm}, 6 \mathrm{~mm}, 8$ $\mathrm{mm}$, and mixture of: $10 \% 3 \mathrm{~mm}+90 \% 8 \mathrm{~mm}, 30 \% 3 \mathrm{~mm}$ $+70 \% 8 \mathrm{~mm}, 50 \% 3 \mathrm{~mm}+50 \% 8 \mathrm{~mm}, 70 \% 3 \mathrm{~mm}+30 \%$ $8 \mathrm{~mm}$, a selection was done of feature based on $\mathrm{R}^{2}$ value.

It can be seen from Table 2 that most effective parameters are Variance, S, K, and L. Another requirement was that the features should not be affected by particle size. Among all the effective features, the parameter which was not affected by the variation of particle size was skewness (S). Figure 10 shows a plot of skewness (S) with particle size and moisture.

Table $2 R^{2}$ values after fitting feature (Mu, Variance, $\left.S, K, G, H, L\right)$ over moisture for different particle sized sample

\begin{tabular}{|c|c|c|c|c|c|c|c|}
\hline Particle size & Mu & Variance & S & K & G & H & L \\
\hline $100 \% 1 \mathrm{~mm}$ & 0.88 & 0.87 & 0.88 & 0.92 & 0.23 & 0.53 & 0.75 \\
\hline $100 \% 3 \mathrm{~mm}$ & 0.87 & 0.96 & 0.86 & 0.86 & 0.95 & 0.64 & 0.92 \\
\hline $100 \% 6 \mathrm{~mm}$ & 0.37 & 0.77 & 0.88 & 0.90 & 0.37 & 0.54 & 0.52 \\
\hline $100 \% 8 \mathrm{~mm}$ & 0.79 & 0.85 & 0.86 & 0.84 & 0.46 & 0.62 & 0.87 \\
\hline $10 \% 3 \mathrm{~mm}-90 \% 8 \mathrm{~mm}$ & 0.59 & 0.54 & 0.60 & 0.56 & 0.34 & 0.45 & 0.55 \\
\hline $30 \% 3 \mathrm{~mm}-70 \% 8 \mathrm{~mm}$ & 0.53 & 0.77 & 0.86 & 0.81 & 0.48 & 0.67 & 0.60 \\
\hline $50 \% 3 \mathrm{~mm}-50 \% 8 \mathrm{~mm}$ & 0.54 & 0.93 & 0.83 & 0.91 & 0.77 & 0.93 & 0.96 \\
\hline $70 \% 3 \mathrm{~mm}-30 \% 8 \mathrm{~mm}$ & 0.79 & 0.84 & 0.87 & 0.85 & 0.41 & 0.04 & 0.70 \\
\hline
\end{tabular}

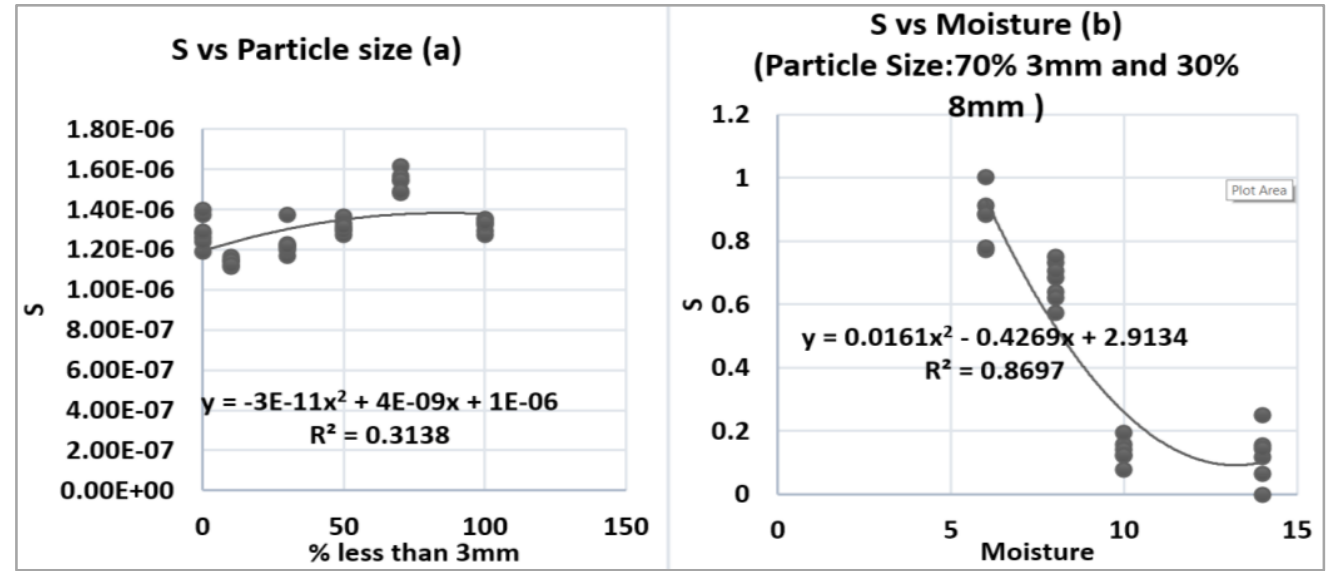

Figure 10 (a) The features (i.e. S) with particle size, (b) S vs moisture for one of the particle size distribution sets (i.e. $70 \% 3 \mathrm{~mm}$ and $30 \% 8 \mathrm{~mm}$ ) among all eight sets for demonstration

\section{Conclusion}

The experiments were first carried out in the laboratory and then on an industrial scale. Optimal placement and height of light source and camera were determined so that both moisture and particle sizes could be determined simultaneously from a single image. The percentage of particles of $-3 \mathrm{~mm}$ size was determined with the mean inaccuracy of $\pm 9 \%$. Moisture content on the surface of coal, varying in the range of $0-20 \%$ moisture, was determined with an accuracy of $\pm 10 \%$ of the moisture value. It is found that the coal moisture saturated after $12 \%$. In industry, the particle size and moisture vary frequently. The modified method of present 
work offers a simple solution to measure both moisture and particle size online from a single accurate measurement but a practical limitation is that the moisture should not exceed $12 \%$.

\section{References}

[1] Woodward, R.C., Lee, B. (1996) On-Line Coal Analyzers for Payment Purposes-What Are You Waiting For?. International Coal Testing Conference, Cincinnati, 1-14.

[2] Zhang, R., Cheng, S., Guo, C. (2017) Detection Method for Pulverized Coal Injection and Particles in the Tuyere Raceway Using Image Processing. University of Science and Technology Beijing, China. http://dx.doi.org/10.2355/isijinternational.ISIJINT2017-433

[3] Khatri, P., Choudhary, P., Deo, B., Bose, S.S., Malakar, P., Pothal, G., Chattopadhyay, G. (2019) Determination of surface moisture and particle size distribution of coal using on-line image, processing. Proceedings of XIII International Mineral Processing and Recycling Conference, University of Belgrade, Technical Faculty in Bor, 14-27.

[4] Heyduk, A. (2018) Machine Vision Monitoring and Particle Size Feed Analysis. Mining - Informatics, Automation and Electrical Engineering, 4 (533) (1), 7. https://doi.org/10.7494/miag.2018.1.533.7

[5] Igathinathane, C., Ulusoy, U. (2012) Particle Size Distribution Analysis of Ground Coal by Machine Vision Volume Approach. 26th International Mineral Processing Congress, IMPC 2012: Innovative Processing for Sustainable Growth - Conference Proceedings, (924), 5581-5593.

[6] Kumara, G.J.J., Hayano, K., Ogiwara, K. (2012) Image analysis techniques on evaluation of particle size distribution of gravel. Int. J. Geomate., 3(1), 290-297.

[7] Sakti, M.B.G., Komariah, A., Sumani, D.P. (2018) Estimating Soil Moisture Content Using Red-GreenBlue Imagery from Digital Camera. IOP Conference Series: Earth and Environmental Science, 200(1). https://doi.org/10.1088/1755-1315/200/1/012004

[8] Shanthi, C., Porpatham, R.K., Pappa, N. (2014) Image Analysis for Particle Size Distribution. International Journal of Engineering and
Technology, 6 (3), 1340-1345.

[9] Thurley, M.J. (2009) Automated online measurement of particle size distribution using 3D range data. IFAC Proc., 42, 134-139. 10.3182/20091014-3-CL-4011.00025

[10] Zhang, Z. (2016) Particle Overlapping Error Correction for Coal Size Distribution Estimation by Image Analysis. International Journal of Mineral Processing, 155, 136-139. https://doi.org/10.1016/j.minpro.2016.08.016

[11] Bennet, T., Liu, H., Bai, X., Yan, Y., Sarroza, A., Lu, G., Eastwick, C. (2017) Combustion Behavior Profiling of Single Pulverized Coal Particles in A Drop Tube Furnace Through High-Speed Imaging and Image Analysis. Experimental Thermal and Fluid Science, 85, 322-330.

https://doi.org/10.1016/j.expthermflusci.2017.03.01 8

[12] Zhu, Y., Wang, Y., Shao, M., Horton, R. (2011) Estimating Soil Water Content from Surface Digital Image Gray Level Measurements Under Visible Spectrum. Canadian Journal of Soil Science, 91(1), 69-76. https://doi.org/10.4141/cjss10054

[13] Zhang, Z., Yang, J. (2017) Online analysis of coal ash content on a moving conveyor belt by machine vision. Int. J. Coal Prep. Util., 37, 100-111. 10.1080/19392699.2016.1140650

[14] Shah, C., Choudhary, P., Deo, B., Malakar, P., Sahoo, S.K., Pothal, G., Chattopadhyay, P. (2019) Conventional and $\mathrm{Al}$ models for operational guidance and control of sponge iron rotary kilns at TATA sponge, Advances in Intelligent Systems and Computing, 816, 461-469. https://doi.org/10.1007/978-981-13-1592-3_36

[15] Kontny, M. (2017) Machine vision methods for estimation of size distribution of aggregate transported on conveyor belts. Silesian University of Technology, Gliwice, Poland. https://doi.org/10.21595/vp.2017.19151

[16] Maloo, T. (2019) Image-processing-for-particlesize_using_MATLAB, April 062020. https://github.com/tanmaymaloo/image-processingfor-particle-size

[17] Zhang, Z., Yang, J., Wang, Y., et al (2014) Ash content prediction of coarse coal by image analysis and GA-SVM, Powder Technol, 268, 429-435. 


\title{
ODREĐIVANJE VLAGE NA POVRŠINI UGLJA I RASPODELE VELIČINA ČESTICA PRIMENOM ONLAJN OBRADE SLIKA
}

\author{
P. Choudhary ${ }^{1}$, T. Maloo², H. Parida², P. Khatri², B. Deo", P. Chattopadhyay ${ }^{3}$ \\ ${ }^{1}$ IIT Bhubaneswar, School of Mechanical Sciences, Odisha, India \\ 2IIT Bhubaneswar, School of Minerals, Metallurgical and Materials Engineering, Odisha, India \\ ${ }^{3}$ Tata Steel Long Products Limited, Joda, Odisha, India
}

(Primljen: 3. april 2020.; Prihvaćen: 29. jun 2020.)

\begin{abstract}
Izvod
Proizvodnja sunđerastog gvožđa zahteva rudu gvožđa, ugalj i dolomit. Na kvalitet sunđerastog gvožđa utiče veličina čestica i sadržaj vlage u sirovini. $U$ ovom radu je primenjena onlajn obrada slika za određivanje veličine čestice i promene vlage $u$ sirovini. Nepravilnosti šuma i signala na slikama su uklonjeni putem analize slika u MATLAB okruženju. Slike sloja uglja na pokretnoj traci su snimane u kontinuitetu (onlajn, na svakih 30 minuta). Određivanje raspodele veličine čestica i vlage na površini uglja onlajn je predstavljalo izazov. Raspodela reflektivnosti uglja na slikama je varirala zavisno od sadržaja vlage $i$ veličine čestica. Intenzitet obrade informacija sa slika je takođe uticao na postupak, koje su nakon obrade korišćene za predviđanje sadržaja vlage na površini uglja. Ovaj metod se danas uspešno koristi u postrojenju za preradu.
\end{abstract}

Ključne reči: Obrada slika; Mašinski vid; Ugalj; Raspodela veličine; Sadržaj vlage; Rotaciona peć. 